\title{
Double Toil and Gender Trouble? Performativity and Femininity in the Cauldron of Esotericism Research
}

\author{
Manon Hedenborg White
}

"Double, double toil and trouble; / Fire burn and cauldron bubble." Thus chant the three potion-brewing witches ominously in Shakespeare's Macbeth (4.1.10-38). The witch's cauldron is a fitting starting point for an exploration of (Western) esotericism, gender, and femininity. Boiling and brewing, poisoning and stewing, have gendered connotations, evoking the labor of house chores - socially coded as feminine - and the historically misogynistic stereotype of the witch that has been subject to feminist reworkings in modern esotericism and Paganism (Hanegraaff, 2002). The witches' song-and the stirring of a proverbial pot or cauldron - conjures the idea of trouble. Analytically, troubling or causing trouble can mean challenging taken-for-granted categories - surface and core, dominance and subjugation, female and male. The queer associations of the term "trouble" are epitomized by Judith Butler's paradigmatic work of queer theory, Gender Trouble (1999).

The late 196os witnessed the emergence of women's studies or women's history as a distinct academic domain, with feminist scholars bringing attention to the obscuration of women's historical contributions to culture and society. Over time, this corrective focus on women gave way to analyses of masculinity and femininity as socially constructed. As highlighted by Joan W. Scott (1986), the growing preference for the term "gender" over that of "women's studies" in academia reflects an understanding that neither women's nor men's social experiences happen in isolation. Simone de Beauvoir's (1987, p. 267) famous declaration that "[o]ne is not born, but rather becomes, a woman" epitomizes the view that what is perceived as feminine and masculine is socially constructed, rather than the outward manifestations of some natural, gendered essence. A distinction between physical sex and social gender allowed feminist scholars to theorize the roles and expectations attached to masculinity and femininity as separate from the supposedly "natural" bodies they were projected onto. From the 199os on, postmodern and poststructuralist interventions have challenged this division, with scholars of queer theory - a paradigm emerging from the intersection of gender and gay and lesbian studies-highlighting the link between the construction of sex, gender, and sexuality. The term queer is often used to indicate configurations of gender and sexuality that displace het- 
erosexuality and/or binary gender, or dominant concepts thereof (cf. Warner, 1993). Gender and queer studies scholars question the idea of a natural and deterministic link between (con)genital morphology, social roles, and desire, believing that concepts such as masculinity and femininity, heterosexuality and homosexuality, are to some extent socially constructed and historically variant. However, they disagree on many points, some of which will be highlighted herein. Thus, while the present article will stir the proverbial cauldron with particular theoretical precepts, the study of gender in esotericism does not require fealty to specific theoretical frameworks.

Recent decades have witnessed the publication of a number of works addressing issues of gender in esotericism (e.g. Braude, 1989; Owen, 1989; Kraft, 1999; Dixon, 2001; Owen, 2004; Snoek and Heidle, 2008; Ferguson, 2012; Lowry, 2017; Hedenborg White, 2020). Several of these studies have focused on esoteric movements - especially around the fin-de-siècle — with a large female presence, such as Spiritualism and Theosophy, exploring how these movements functioned as forums for alternative views on gender. Much remains to be done-not least in terms of interrogating how esotericism as an object, and the scholarly study thereof, is demarcated (cf. Johnston, 2014; 2015). Given the historical marginalization of women and femininity from hegemonic institutions of knowledge production, the notion of esotericism as "rejected knowledge" (Hanegraaff, 2012) could productively be engaged from perspectives of gender. Discussing Spiritualism, Elizabeth Lowry (2017, p. xxvii) links Hanegraaff's historical analysis of the academy's "ostentatious performance of skepticism" towards esotericism with a feminist-historiographic endeavor to recover and take seriously women's experiences. The association of the slippery category of magic with women, the working classes, gendered and sexual deviance, and various racialized "Others" (cf. Styers, 2004, pp. 14-18; Bogdan, 2012, p. 2) is also fertile ground for future research. Simultaneously, the idea of esotericism as "rejected knowledge" is complicated by the fact that esotericisms have sometimes replicated foundational discourses of Western modernity, such as (white) European supremacy or masculine rationality (cf. Bakker, 2019; Asprem, 2021).

Rather than venture into this meta-conceptual discussion or review the state of research, this article will zoom in on a particular material: instances of modern esoteric ritual drawn from the religion Thelema, founded in 1904 by the British occultist Aleister Crowley (1875-1947). I have conducted historical and ethnographic research on Thelema since 2012 (for details, see Hedenborg White, 2013; 2020, pp. 8-10). Herein, I will analyze experiences of Crowley's Gnostic Mass, written in 1913, and three rituals oriented toward the Thelemic goddess Babalon that were scripted from the 199os on. All four rituals con- 
tain elements likely to be familiar to students and scholars of esotericismrecitation of historical esoteric texts, visualization, vibration of divine names, banishing, invocation, the tracing of shapes in the air, symbolic correspondences, and references to the kabbalistic Tree of Life. Crucially, they also entail performances of femininity (see subsequent section) that relate to hegemonic gender logics in complex ways. These gendered aspects are, arguably, neither inconsequential nor superficial, but are integral to the rituals' social function and (perceived) transformative power. Aided by gender and queer theoretical frameworks, it is possible to disentangle some aspects of esotericism that may otherwise be overlooked, contributing to a fuller understanding of esoteric worldviews and practices, and the inscription and challenging of power relations therein.

\section{1 \\ Theoretical Framework: The Performance of Femininity}

My analysis herein will draw on two central concepts: performativity and femininity. Judith Butler has challenged the distinction between biological sex and sociocultural gender. Not contesting the fact of bodily difference, Butler argues that the mapping of a myriad of bodily differences onto an incommensurable, yet complementary, sexual binary is a social construction (e.g. Butler, 1993, pp. 10-11, 66-67). Understandings of biological sexual difference are culturally produced and entangled with social expectations, and thus it is problematic to speak of a pre-discursive, sexed body onto which social gender is then projected. Instead, understandings of biological sex are historically situated and culturally variant.

Butler views gender as performative. Her notion of performativity is inspired by the philosopher of language J.L. Austin's distinction between constative and performative language. Simply put, constative utterances can be verified as true or false (i.e., "the sky is blue"), while performative utterances are such that their very pronouncement changes social reality (i.e., "I now pronounce you husband and wife," "I promise you that...") (e.g. Butler, 1993, pp. 10-11, 243-246). Butler's concept of performative gender thus means that there is no essential gendered identity that structures behavior-instead, people are gendered through continuous repetition of behaviors that suggest an underlying gendered essence. In other words, gender is something one does, rather than something one is or has (see also West and Zimmerman, 1987). This does not imply that gender is a "choice," in the sense that one may choose one's shoes. Rather, gender is continuously reproduced via imitation of a limited number of culturally intelligible ways of "doing gender," and this process 
is intimately linked to the construction of selfhood. Gender is relationalnotions of masculinity acquire meaning in relation to notions of femininity, and so on (e.g. Butler, 1999, pp. 33-43, 142). Being gendered thus means part of that which constitutes one's identity is situated outside of oneself (Butler, 2004, p. 19). However, the performative nature of gender means that it is possible to destabilize hegemonic gender logics by doing gender in creative ways that scramble or stretch the existing categories (Butler, 1999, p. 43).

Though approaches to gender as performative can be used to elucidate esoteric practices in numerous ways, this article will especially highlight performances of femininity. Anthropologist and gender studies scholar Ulrika Dahl notes that femininity "has had a bit of a bad reputation in feminist theory; far too often tied to phenomena feminism seeks to eliminate; subordination, sexualisation, objectification, commodification, vulnerability, and so on" (Dahl, 2016, p. 7). Illustratively, American legal scholar and radical feminist theorist Catharine MacKinnon (1982, p. 531) argued in the 1980s that femininity, as a social ideal of womanhood, means "[sexual] attractiveness to men ... sexual availability on male terms." MacKinnon claimed that "what defines woman as such is what turns men on," and her equation of femininity with attractiveness to the male gaze is representative of much radical feminist theorization on femininity. Drawing on a Foucauldian analysis of power and discipline, Sandra Bartky (1988) has argued that bodily practices such as dieting and feminine fashion styles produce a body that is docile, object-like, and vulnerable to attack. In Bartky's (pp. 146-147) view, women must discard femininity if they are to gain equality. Similarly, according to Susan Brownmiller (1985, p. 81), investment in "feminine fashion" means being "obsessively involved in inconsequential details on a serious basis." In Brownmiller's (1985, p. 86) words, feminine styles of dress are inherently uncomfortable, as "practicality is a masculine virtue," and being "truly feminine is to accept the handicap of restraint and restriction, and to ... adore it."

MacKinnon, Bartky, Brownmiller and similar theorists share an understanding of femininity and its associated bodily styles as a debilitating mask, which women can and should discard. During the 1980s "sex wars"-intra-feminist disputes surrounding sexuality - radical feminists extended their critique of femininity to lesbian femmes. The term "femme" (sometimes spelled fam) originated in 1940 s working-class lesbian bar culture, where it denoted a "feminine" lesbian who desires a "masculine" lesbian or butch (cf. Lapovsky Kennedy and Davis, 1993). Many radical feminists accused femmes of replicating a heterosexist standard of feminine beauty (e.g. Jeffreys, 1987). Radical feminists were also critical of pornography and BDSM, viewing these as heightened forms of patriarchal sexual violence (e.g. Linden et al., 1982). Femmes re- 
sponded to radical feminist critiques by arguing that their deliberate and often exaggerated femininity did not replicate heterosexist standards, instead constituting a brazen form of gender subversion that flouted the conventions of heterosexual, feminine respectability (e.g. Duggan and McHugh, 1996). Simultaneously, sex radical feminists critiqued the tendencies toward sexual prescriptivism among radical feminists, calling for an analysis of feminine sexuality that accounts both for "pleasure and danger," power and resistance (e.g. Vance, 1992).

The assumption that femininity is always structured by and performed for a male gaze fails to take seriously queer feminine desire. The radical feminist critiques of femininity also disregarded the fact that not all who are (seen as) feminine are women. Crucially, what is viewed as appropriately feminine is not only defined in relation to maleness or masculinity, but through numerous intersections of power including race, sexuality, ability, and social class. In other words, white, heterosexual, binary gender-conforming, able-bodied, and upper- or middle-class femininity is privileged in relation to other varieties. Any social system may contain multiple femininities that differ in status, and which relate to each other as well as to masculinity. As highlighted by "effeminate" gay men, trans women, femmes, drag queens, and "bad girls," it is possible to be perceived as excessively, insufficiently, or wrongly feminine without for that sake being seen as masculine. Finally, the view of femininity as a restrictive yet disposable mask presupposes that emancipation entails departure into neutral (or masculine) modes of being. This is a tenuous assumption, as the construction of selfhood is entangled with gender, and conceptions of androgyny and gender neutrality similarly hinge on culturally specific ideas of masculinity and femininity.

Within this article, femininities will be seen as symbolic constructions tied to clusters of characteristics and behaviors that are perceived as womanly (cf. Schippers, 2007), and which are neither exclusively heterosexual nor only inhabitable by women. Femininity does not simply emanate from or conceal some supposedly "authentic" version of womanhood, but is performatively produced and enacted in historically, culturally, and contextually variant ways. Following scholars of queer femininities such as Ulrika Dahl (e.g. 2010; 2016; 2017) and Hannah McCann (2018), I am skeptical of assumptions that particular iterations of femininity (such as femme, or the ritual roles analyzed below) are inherently more emancipatory simply on the grounds of being intentional or deliberate. Concurrently, I will consider femininities as positionalities that entail both agency and being acted upon (cf. Butler, 2014). Elizabeth Lowry has highlighted this potential of femininities with regard to nineteenth-century Spiritualist mediums. Female Spiritualists negotiated the space between the 
idealized cult of "True Womanhood" - represented by the pious, chaste, and domestic woman - and the brazen and often stigmatized "New Woman." Instead, they drew on the ideal of "Real Womanhood" - a frequently overlooked model of femininity occupying a sort of middle ground and which emphasized practicality, strength, and courage (Lowry, 2017, pp. x-xx).

It will be assumed herein that gendered attributes (such as dress or adornment) are neither inherently oppressive nor liberating. Instead, they will be seen as linked both to regimes of power and the possibility of resistance theretoward. Particular behaviors or bodily styles may connote femininity in one particular context and not another. In the context of late-modern, North American and European culture, for example, high heels, lace lingerie, emphasized makeup, and long hair-especially in combination-are part of a socially constructed feminine aesthetic. As will become evident below, these attributes are recognizable to esotericists who utilize them partly because of their broader cultural connotations. However, these attributes also gain particular meaning in some Thelemic ritual contexts. As will be discussed in the subsequent section, nakedness - seemingly divested of the gendered cultural attributes of dress-also communicates a specific femininity with particular assumptions attached to it in the context of the Gnostic Mass.

\section{2 'Bare and Rejoicing': The Naked Priestess of the Gnostic Mass}

In 1904, Aleister Crowley received what he perceived as a divinely inspired text, later given the title Liber $A L$ vel Legis (abbreviated Liber $A L$ ), and colloquially known as The Book of the Law. Divided into three chapters attributed, respectively, to the goddess Nuit, the god Hadit, and the god Ra-Hoor-Khuit, this text proclaims: "Do what thou wilt shall be the whole of the Law" ( $A L$ I:40). In 1912, Crowley was made head of the British branch of the initiatory fraternity Ordo Templi Orientis (ото). He proceeded to reshape ото's degree structure and rituals in accordance with Thelema, penning the so-called Gnostic Catholic Mass for the order in 1913. Though structurally similar to the Tridentine Mass, Crowley's ritual celebrates the Thelemic cosmology. According to Crowley, the Gnostic Mass communicates the central mystery of ото, generally held to be a particular formulation of sexual magic. From 1914, Crowley systematically explored sexual magic with a plethora of female and male partners (see e.g. Crowley, 1972, pp. 1-82).

The Gnostic Mass is conducted by a priest and priestess, aided by a deacon and two "children." A cursory and selective outline (which does not account for the roles of deacon or children) follows: the priestess, dressed in "white, 
blue, and gold" and bearing a sword from a "red girdle," enters the temple and raises the priest from his "tomb." Crowley's instructions for the priestess's dress leave room for variations. It is common for her to wear a blue robe, dress, or tunic, but cut, length, and fabric vary, as do- to a greater extent-hair, makeup, jewelry or lack thereof. The priest, wearing a white tunic and carrying a lance, proclaims: "I am a man among men." The priestess purifies and consecrates him with instruments representing the four elements. She robes and crowns him, proclaiming his ascension from mortal man to "priest of the sun." The priest aids the priestess onto a high altar, purifying and consecrating her before drawing a veil to conceal her. He invokes the goddess Nuit while the priestess disrobes completely. She delivers her own address, drawn from the first chapter of Liber AL, attributed to Nuit. As explanation for the priestess's nudity, Crowley quotes from the same chapter, which states that the priestess should stand "bare and rejoicing" whilst calling to her celebrants $(A L$ I:62). Having delivered her invocation, the priestess can choose to re-robe or remain naked, while the priest invokes the divine masculine (as Hadit). The priest then opens the veil revealing the priestess to the congregation, and priest and priestess jointly consecrate the Eucharist. They enact the "Mystic Marriage" (a symbolic sexual union) by lowering the priest's lance into a wine-filled grail, after which the priest-followed by the rest of the congregation-consumes the Eucharist, proclaiming: "There is no part of me that is not of the gods" (Crowley, 2007, pp. 247-270).

Conducted under the auspices of Ecclesia Gnostica Catholica (EGC), the ecclesiastical arm of ото, the Gnostic Mass is celebrated hundreds of times annually across the globe. Since 2012, I have observed approximately 40 performances of the Gnostic Mass, mostly in the United States. I have also conducted semi-structured interviews and countless informal conversations with priests and priestesses of EGC. These exchanges have revealed a variety of interpretations and local variations, including how priestesses choose to present themselves as the veil opens. For instance, some priestesses who elect to remain disrobed retain adornments such as jewelry or body art. Others re-robe only partly, or don underwear in significant colors. The priestess's nakedness is often interpreted as symbolic of her identification with Nuit, traditionally represented as a naked woman stretching across the sky (inspired by the iconography of the Egyptian sky-goddess Nut). This is unsurprising, given how the mass script draws on the chapter of Liber $A L$ attributed to this deity. However, the nakedness of the priestess is ascribed multiple and contradictory meanings within the Thelemic milieu. Many contemporary Thelemites have told me that the priestess's disrobing - whether or not she re-robes before reappearing before the congregation-both marks and contributes to her transformation 
into goddess. This parallels how the male officiant's robing and crowning at the hands of the priestess marks and effects his transformation from "man" to "priest."

The priestess's and priest's dress changes as understood by the Thelemites I have spoken to are performative-altering social relations within the ritual space by contributing to the clergy members' (perceived) transition into divine embodiments. The social reality of the mass is gendered-as the priest transforms into the masculine divine, the priestess becomes representative of an aspect of the feminine divine and the attributes that are ascribed thereto in this specific context. Importantly, it is common for Thelemites to associate Nuit with receptivity and openness, in contrast to the perceived activity of the masculine principle (Hedenborg White, 2013, p. 107). While many Thelemites reflect critically on the idea of femininity as receptive (see Hedenborg White, 2020, pp. 211-215), the nakedness of the priestess may contribute to the idea of feminine nudity and receptivity as intertwined. Sophie, a longtime EGC priestess stated of her experience of appearing on the altar in the mass: "You're vulnerable every way you can be. You're energetically wide open" (quoted in Hedenborg White, 2020, p. 213). This highlights how the femininity of the priestess-as-Nuit can be associated with "traditionally" feminine attributes such as vulnerability.

Contemporary Thelemites' reflections on the Gnostic Mass illustrate that the meaning of esoteric ritual is neither fixed nor determined by authorial intent. Instead, the meaning of ritual is continuously negotiated, and broader tendencies and perceptions among practitioners may impact attitudes towards ritual practice. While a dearth of large-scale, quantitative studies renders it difficult to generalize about contemporary Thelemites' values, Anglo-American Thelemites are seemingly more likely than average to support non-normative gendered and sexual modalities (cf. Hedenborg White, 2020, pp. 197-198). My research suggests feminism and the LGBTQ movement have impacted the landscape of contemporary Thelema (at least in the US) from the 199os onwards, coinciding with an increase in attempts to promote the voices of female Thelemites (e.g., separatist discussion groups, podcasts, and publications) as well as critical emic discussion of gender and magic in relation to trans and queer experience (cf. Hedenborg White, 202O, pp. 195-202). This has implications for the performance of femininity in the Gnostic Mass. The ото's United States Grand Lodge (the largest and most bureaucratized national grand lodge) stipulates that the priestess should be a woman and the priest a man in "public" (i.e., open to non-initiates) mass celebrations. Alterations are permitted in "private," initiates-only masses. Transgender clergy may perform the mass publicly in the clerical role corresponding to the gen- 
der with which they most closely identify (cf. Hedenborg White, 2013). Nonbinary/genderqueer individuals have the option of performing the mass in the role corresponding to their birth-assigned gender (or as deacon or "child"). While opinions diverge regarding these conventions, the ongoing discussions and the explicit use of language denoting trans and genderqueer/non-binary experience in ото policies attests to the impact of LGBTQ discourses on the Anglo-American Thelemic landscape.

Increasing Thelemic engagement with feminist ideas has coincided with varying responses to the priestess's nudity. Several female Thelemites to whom I have spoken were critical of the fact that the priestess is naked while the other ritual officers and congregation are clothed, questioning whether this reduces women to objects of male sexual enjoyment. This reflects feminist concerns with sexual objectification as a form of gendered oppression, as exemplified by the radical feminist critiques cited above. I have also spoken to EGC priestesses who attest to having, on one or several occasions, felt objectified by male members of the congregation.

Emic responses to this critique are varied, sometimes citing a combination of magical, pragmatic, and social rationales. For instance, one EGC priestess I interviewed stated that the priest could conceivably also appear naked, but that symbolic accuracy would require him to maintain an erection throughout the ceremony (after the priestess "awakens" him from his tomb), and that this would be difficult for many males to accomplish in front of an audience. Thus, the priest is robed and the erect lance is used to symbolize the awakened masculine principle. I have also interviewed numerous EGC priestesses who attribute emancipatory (even feminist) potential to the mass. They describe the experience of appearing naked on the altar as liberating and suggest that the naked priestess - far from objectified - challenges misogynistic perceptions of women's bodies and sexuality as deficient or impure. As Amy, a long-time EGC priestess told me: "How do we convince people that the female body isn't really dirty and gross? Well, we can talk about it all day, or a couple times a month we can put a naked female body on the altar and have everybody kneel" (quoted in Hedenborg White, 2020, p. 231). Similarly, Thelemic author Brandy Williams (2009) suggests that the mass can challenge misogynistic perceptions of femininity by showing women as direct representatives of divinity. These interpretations dovetail with sex radical feminist arguments that link female emancipation to sexual liberation.

The point here is not to deduce who is right, but rather to highlight that something as seemingly simple as a naked body is anything but. The priestess's disrobing is not just a stripping of the gendered cultural attributes of dress that uncovers a "natural" naked body, revealing a femininity that exists 
irrespective of cultural conventions. Instead, the act can be understood as an instance of gender performativity: it shifts the priestess's body from one iteration of femininity (that of priestess) and materializes a different one (that of goddess), both of which are perceived and experienced as sacred in their particular context. This iteration of femininity is not autonomous of dominant gender logics, as evinced by the critical voices questioning whether the naked priestess is objectified. As seen above, the priestess is also associated with conventionally feminine characteristics such as receptivity and vulnerability. Nonetheless, while the sequence is scripted, it is never replicated identically, and there is the possibility for individual creativity. The nudity of the priestess may be read as a challenge to notions of women's value as contingent on sexual modesty, or binary oppositions of masculinity/spirit and femininity/matter. Either way, esotericists interpret the naked priestess of Nuit not only in relation to esoteric teaching, but also in relation to logics of gender in society more broadly, sometimes reading the nakedness of the priestess as a statement about gender - as providing a particular vision of femininity may engender both feelings of emancipation and sacredness, or politically informed skepticism.

\section{3}

\section{Scarlet Harlots: Femininity and the Goddess Babalon in Ritual}

A central focus for my research on Thelema and gender has been historical and contemporary interpretations of the Thelemic goddess Babalon. Babalon is based on Crowley's favorable reinterpretation of the biblical Whore of Babylon (Rev. 17) and is associated with liberated feminine sexuality and the mystical formula of ecstatic union with all. Crowley in his descriptions of Babalon and the related figure of Scarlet Woman, conceived as Babalon's earthly emissary, emphasized many of the same characteristics as her biblical prototype: promiscuous sexuality, eroticized feminine attire, and worldly power (e.g. Crowley, 1974, pp. 261-282; 1998, AL III:43-45). Crowley upheld these traits as indexical of Babalon's sacredness, positioning her as a counter-image to fin-desiècle ideals of femininity as chaste, nurturing, and passive. By conceptualizing Babalon as symbolic of the soteriological ideal of ego destruction and union with all, Crowley also positioned the goddess-and the feminized mode of being she is associated with — as an ideal for all seekers (cf. Hedenborg White, 2020, pp. 43-46, 66-70).

Over the twentieth- and twenty-first centuries, numerous esoteric practitioners have continued to interpret Babalon, sometimes with a critical eye to Crowley's writings on this symbol and the role of the Scarlet Woman. Whereas 
Crowley appears mainly to have viewed the Scarlet Woman as a role available to women who played particular roles in his life and initiation, a number of later esotericists (many of them female) have stressed that women can and should claim the role for themselves, independently of any partner (male or otherwise). This is also the case in two of the below rituals. Especially from the 199 os onward, the goddess has frequently been construed in emic discourse as a challenge to limited concepts of femininity, and as an image of feminine power beyond misogynistic tropes (Hedenborg White, 2020).

In this section, I will analyze the performance of femininity in three Babalon rituals, relayed to me second-hand in written or oral format. ${ }^{1}$ The first ritual "Procession of Babalon," written by Aisha Qadisha (1996), was performed during the 1996 Thelemic Women's Symposium - one of several initiatives undertaken in recent decades to promote female Thelemites' voices. A collective ritual, it presents a succession of three historical epochs associated with different approaches to the divine feminine, who is embodied by three women ritual practitioners as the Semitic goddess Astarte, the Virgin Mary, and Babalon. The cultural meanings ascribed to these figures are conveyed through clothing, posture, and speech. Astarte wears a "loose, flowing robe or gown in ancient style." She states that women's bodies and sexuality were held as sacred in pagan antiquity. The Virgin Mary is dressed in a "blue and white gown ... with halo," her eyes lowered in shame. She speaks instead of female sexual repression under Christianity. In stark contrast, Babalon wears a red wig and a red bra and garter with high heels and stockings. Triumphantly, she heralds the social and sexual liberation of women, addressing the (female) ritual participants as her daughters and calling them to carry themselves victoriously, "laugh[ing] and danc[ing] as the dying god crumbles," their laughter being as "the cackle of harlots in a house of fornication." The juxtaposition of Astarte's "ancient style" get-up and Mary's modest attire with Babalon's unabashedly ultrafeminine and eroticized outfit can be interpreted as a challenge to the notion of feminine value as contingent on modesty, reclaiming the negatively stereotyped femininity of "harlot" as indexical of power, sacredness, and sexual freedom.

The second ritual was described to me by Freyja, a female Thelemite and feminist. Freyja conducted the ritual with her male romantic partner James. While James was dressed inconspicuously in black, Freyja donned a low-cut red dress and eye-catching gold jewelry, applying red lipstick and dark eye

1 I have analyzed these rituals in greater detail elsewhere, see Hedenborg White, 2020, pp. 291-320. 
makeup-heavier, she observed, than she would ordinarily use. She stated that she donned this ultrafeminine attire as she associates this "look" with Babalon. Given her aim to embody a goddess associated with unabashed feminine sexuality, she believed it would be helpful to encourage James's desire for her. However, Freyja noted that she has worn similar attire when invoking Babalon alone, feeling it is pleasing to the goddess. This evinces that Freyja's dress and adornment was not only aimed to attract a male partner (though it was partly the reason). Practicality was also a concern-having scripted a dance sequence into the ritual, Freyja opted against high heels. After a series of preparatory invocations-Crowley's "Star Ruby" and "Liber V vel Reguli" rituals-James purified and consecrated Freyja in a manner similar to that of the priest and priestess in the Gnostic Mass. The couple took turns reciting texts pertaining to Babalon, mostly derived from Crowley's oeuvre. Freyja proceeded to dance ecstatically, while James recited a passage from Crowley's "Liber Samekh" that mentions Babalon (Crowley, 1994, p. 509) as a mantra. Afterward, James removed Freyja's clothing, bound her hands, and administered 156 (derived from the gematria value of the name Babalon) blows to her back with a whip, while Freyja used Babalon's seal — a seven-pointed star inscribed with her name first printed in Crowley's The Book of Lies (1912) - as a meditative focus. The couple shared a sacramental glass of red wine, had sex, and meditated silently before concluding.

The third ritual was designed by esoteric author Soror Syrinx. Syrinx has written several introductory manuals for esotericists (principally women, though she writes her rituals can be utilized by all) who are interested in the role of Scarlet Woman. She frequently critiques sexism in society and stresses the importance of female emancipation, articulating the figure of the Scarlet Woman as a challenge to narrow stereotypes of femininity. The ritual of interest here is one of solitary adoration, through which Syrinx writes that a female magician can begin to identify herself with Babalon before engaging in partnered sexual magic. Syrinx instructs her reader to design an altar with meaningful items such as a seal of Babalon and the "Lust" card of the Thoth Tarot deck-co-created by Crowley and the artist Frieda Lady Harris (1877-1962) — which is associated with Babalon (Crowley and Harris, 1974, pp. 92-95). She is then to don "fine apparel, red or purple," to use makeup creatively, painting her lips "ruby," and her eyes "a heavenly azure," and to cover herself with "glittering jewels." She then suggests visualizing oneself as Babalon while indulging in luxurious fruits, sweets, and wine in order to encourage a sensual and ecstatic state of mind. The ritual culminates in a guided meditation through which the practitioner envisions herself as adrift in a great womb before being reborn as Babalon. After this, Syrinx suggests engaging in 
a creative pursuit such as writing, painting, playing an instrument, or dancing (Syrinx, 2014, pp. 72-74).

The aim of the above exposition has been to indicate how some contemporary esotericists use a feminine aesthetic of dress, jewelry, and makeup to inhabit and communicate the Thelemic goddess Babalon in ritual. We may regard these women esotericists' actions as instances of performative gender, both drawing on and (re)producing particular iterations of femininityassociated with sexual assertiveness (but also submissiveness), aestheticized excess, and sensual pleasure-as subculturally meaningful. While a review of a greater range of rituals would produce a more complex image, representativity has not been the objective here. Instead, this overview will serve as the basis for a critical analysis of femininity, exemplifying the broader importance of gender perspectives for the study of esotericism. Ritual

Why does a ritual practitioner strip naked, don high heels or red lingerie, apply pronounced makeup or allow herself to be bound and whipped for the purposes of esoteric ritual? Read through the radical feminist critiques of femininity outlined in the section on theoretical frameworks, these practices may appear simply as fetishization of female subjugation. However, these actions take place in a religious milieu that has been influenced by feminist thought, and several of the abovementioned female ritual creators and participants articulate these practices as part of an endeavor to redefine femininity in emancipatory ways. Following Dahl, McCann, and other theorists who have suggested femininities as positionalities that entail both vulnerability and agency, I find it too simplistic to read these ritual practices as examples of female sexual objectification for the benefit of a male gaze. No men were present for Syrinx's or Qadisha's rituals - the latter of which emphasizes embodied, sensual relationality between women. While Freyja's ritual involved a male participant, Freyja formulates her relationship with Babalon in terms of both identification and queerly feminine desire.

The notion that the frequently less "practical" nature of contemporary feminine aesthetic styles univocally indicates submissive social status also fails under historical scrutiny. Disregard for practicality is not a universally male prerogative but has often been a privilege of the wealthy and protected, regardless of gender. For contemporary masculine aesthetic styles, practicality does not correlate in simplistic fashion with social status-as exemplified by the pref- 
erence for (or expectation of) suits in many high-status professions and social milieus. Concurrently, "impractical" feminine fashion has frequently been a marker of class and racial privilege (Skeggs, 2001). While practicality and function may be prioritized in esotericists' selection of ritual gear-as highlighted by Freyja's opting against high heels-they are not always prime concerns for either men or women. Instead, ritual implements and garb may be selected for purposes of symbolic accuracy or magical significance (cf. Owen, 2004, pp. 74-75). Similarly, femininity is performed through nakedness or particular clothing in the above-discussed rituals (partly) for reasons of magical significance-female nakedness connotes Nuit, redness and eroticized attire connotes Babalon, challenging negative stereotypes of assertive female sexuality by rendering it emblematic of divine status. These examples showcase how gender performativity functions as a "material citational practice" (cf. Dahl, 2009, p. 56) that acquires meaning and cultural salience in relation to other performances of gender.

As seen in the above-discussed rituals, femininity is performed as both uplifted and vulnerable (as in the case of the Gnostic Mass priestess), assertive and partially restricted. Significantly, Freyja's ritual includes literal physical restriction in the form of bondage, which-especially combined with flagellation-evokes associations to BDSM. This is not uncommon in contemporary esoteric and Pagan milieus, where discourses on "sacred kink" have garnered increased attention in recent years (cf. Mueller, 2017). So, should we see this aspect of Freyja's ritual as a fetishization of feminine submission, signifying - to quote Susan Brownmiller - the association of femininity with "the handicap of restriction"? Once again, I find this potential reading reductive and dismissive of practitioners' own interpretations and the complex ways in which sexual agency may be structured in BDSM and which cannot solely be reduced to stereotypical gender dynamics (cf. e.g. Rubin, 1984; Carlström, 2016).

Nonetheless, reading Freyja's eroticized submission solely as liberal, empowered non-compliance with hegemonic gender norms reproduces a reductive dichotomy of activity and passivity that does not account for how all gendered performances entail both agency and the potential for being acted upon (cf. Butler, 2014; Dahl, 2017). The responses of some female Thelemites to whom I have spoken indicate how ritual practices are not enacted in a social vacuum - neither the priestess nor anyone else can control the responses of others present. Some mass congregants may look at the naked priestess only as a source erotic stimulation, without awareness of the possible religious connotations. In other cases, a certain critical, feminist gaze renders a hypothetical, objectifying male gaze implicitly present whether or not there are men 
in the room. The rituals discussed in this article position femininities as the site of interface between humanity and divinity, while also associating femininity, variously, with receptivity, vulnerability, and (possibly) sexual availability. These are linkages many feminists have sought to deconstruct, but which are also, arguably, foundational to relationality. This is a source of productive tension, as reading these characteristics as solely passive or oppressive risks reproducing the very logics one wishes to challenge. As such, an interrogation of gender, performativity, and esotericism must consider the marginalization of women, gender-nonconforming individuals, and sexual minorities (in society and sometimes in esotericism), while taking seriously these same groups' subjective experiences of esoteric practices as transformative.

I do not suggest these ritual performances of femininity are inherently more subversive than normative, "everyday" femininity simply because they are scripted or deliberate. Such an assumption underestimates the agency of "mainstream" femininities while overestimating the connection between intentionality and subversivity (cf. Dahl, 2010; Walker, 2012). Helpfully, McCann (2018, p. 6) suggests considering feminine appearance and embodiment as having the potential to produce "affects that might work in various directions." Such affects may include unease at the stigma that follows being read by others as feminine, but also comfort at social acceptance, or forms of pleasure and relationality that transcend self-objectification. Similarly, the performances of femininities in the above-discussed rituals generate complex and contradictory affective responses. Reading femininity in these rituals as structured solely by hegemonic gender logics, or as completely autonomous of them, overlooks the complex ways these rituals are alternately perceived as empowering, controversial, or pleasurable.

In this chapter, I have slipped feminist theorization into the proverbial cauldron of esotericism studies not only to understand the rituals discussed herein, but in the hopes that the resulting brew may say something about the complexities of femininity - and gender-more broadly. While the subject matter may appear a narrow case study, I propose that the conclusions drawn have broader applicability. Specifically, they showcase how the construction and reconstruction of gender can be a vital dimension of esoteric practice and its development over time. Self-transformation is a common goal of contemporary esotericists (cf. Mayer, 2009; Granholm, 2014, pp. 134-138, 158-159). Historical and contemporary esotericism provides several examples of how this ideal may be formulated and experienced in gendered terms, such as female Spiritualists' endeavors to redefine femininity in the public sphere (Owen, 1989; Lowry, 2017); the construction of interiorized androgyny and/or hermaphroditism as an initiatory aim among nineteenth- and early-twentieth 
century esotericists (Owen, 2004, pp. 109-111; Strube, 2016, pp. 62-63); rightwing philosopher Julius Evola's insistence on a "masculine' renunciation" (quoted in Hakl, 2018, p. 153); and present-day male adherents of the goddess movement seeking to redefine masculinity in more open ways (Green, 2012). If we only focus on, for instance, how esoteric practice is structured using elements of historical source texts or building on tropes such as correspondences or panentheistic worldviews, without paying attention to gender, we may disregard vital aspects of the social function and meaning of esoteric beliefs, practices, and organization.

Finally, esoteric ritual may provide a fruitful vantage point from which to analyze how all bodies are performatively materialized via selective use (or non-use) of particular aesthetic styles and attributes. The embodied performance of gender cannot be understood simply as operating on a spectrum from functional/practical masculinity to decorative/restrictive femininity. Rather, all forms of bodily adornment replicate and respond to cultural codes and symbols in ways that may both re-inscribe and challenge hierarchies of gender, class, race, religion, sexuality, and other markers of social positionality. While theories of gender and femininity doubtlessly have the potential to stir the cauldron of esotericism studies, esotericism as an object of study offers productive conceptual trouble to the broader study of gender, illustrating how performances of gender are complex and contradictory, having the potential to effect contradictory experiences of politically informed skepticism, sexual arousal, restraint, and sacredness.

\section{Bibliography}

Asprem, E. (2021) "Rejected Knowledge Reconsidered: Some Methodological Notes on Esotericism and Marginality," in Asprem, E. and Strube, J. (eds.) New Approaches to the Study of Esotericism. Leiden and Boston: Brill, pp. 127-146.

Bakker, J.M. (2019) "Hidden Presence: Race and/in the History, Construct, and Study of Western Esotericism," Religion. [Online] DOI: 10.1080/oo48721X.2019.1642262.

Bartky, B. (1988) "Foucault, Femininity and the Modernization of Patriarchal Power," in Diamond, I. and Quinby. L. (eds.) Feminism and Foucault: Reflections on Resistance. Boston: Northeastern University Press, pp. 61-86.

Bogdan, H. (2012) "Introduction: Modern Western Magic," Aries, 12(1), pp. 1-16.

Braude, A. (1989) Radical Spirits: Spiritualism and Women's Rights in NineteenthCentury America. Boston, Mass.: Beacon Press.

Brownmiller, S. (1985) Femininity. New York: Ballantine Books. 
Butler, J. (1993) Bodies that Matter: On the Discursive Limits of "Sex." New York: Routledge.

Butler, J. (1999) Gender Trouble: Feminism and the Subversion of Identity. New York: Routledge.

Butler, J. (2004) Undoing Gender. New York; London: Routledge.

Butler, J. (2014) "Rethinking Vulnerability and Resistance," Instituto Franklin. Accessed July 29, 2020. https://www.institutofranklin.net/sites/default/files/files/Rethinking \%2oVulnerability\%2oand\%2oResistance\%2oJudith\%2oButler.pdf.

Carlström, C. (2016) BDSM: Paradoxernas praktik. Malmö: Malmö University.

Crowley, A. (1972) The Magical Record of the Beast 666. The Diaries of Aleister Crowley 1914-1920. Symonds, J. and Grant, K. (eds.) London: Duckworth.

Crowley, A. (1974) The Magical and Philosophical Commentaries to the Book of the Law. Symonds, J. and Grant, K. (eds.). Montreal: 93 Publishing.

Crowley, A. (1998) The Vision and the Voice: With Commentary and Other Papers: The Equinox, Volume IV Number II. Beta, H. (ed.). York Beach, ME: Samuel Weiser.

Crowley, A. (2004) The Book of the Law: Liber AL vel Legis: With a Facsimile of the Manuscript as Received by Aleister and Rose Edith Crowley on April 8, 9, 10, 1904 E.v. Centennial Edition. York Beach, ME: Red Wheel/Weiser.

Crowley, A. (2007) “Liber Xv: Ecclesiæ Gnosticæ Catholicæ Canon Missæ,” in Crowley, A., The Blue Equinox: The Equinox Vol. III No. I. San Francisco: Red Wheel/Weiser, pp. 247-270.

Crowley, A. and Harris, F. (1972) The Book of Thoth: Short Essay on the Tarot of the Egyptians, Being the Equinox, Vol. III, No. 5. York Beach, ME: S. Weiser.

Dahl, U. (2009) “(Re)Figuring Femme Fashion," Lambda Nordica, 2-3, pp. 43-77.

Dahl, U. (2010) "Notes on Femme-inist Agency," in Jónasdóttir, A.G., Bryson, V., and Jones, K.B. (eds.) Sexuality, Gender, and Power: Intersectional and Transnational Perspectives. New York: Routledge, pp. 172-188.

Dahl, U. (2016) “Queering Femininity," Lambda Nordica, 21(1-2), pp. 7-20.

Dahl, U. (2017) "Femmebodiment: Notes on Queer Feminine Shapes of Vulnerability," Feminist Theory, 18(1), pp. 35-53.

De Beauvoir, S. (1984) The Second Sex. Harmondsworth: Penguin Books.

Dixon, J. (2001) Divine Feminine: Theosophy and Feminism in England. Baltimore: Johns Hopkins University Press.

Duggan, L. and McHugh, K. (1996) “A Fem(me)inist Manifesto," Women \& Performance: A Journal of Feminist Theory, 8(2), 153-159.

Ferguson, C. (2012) Determined Spirits: Eugenics, Heredity and Racial Regeneration in Anglo-American Spiritualist Writing, 1848-1930. Edinburgh: Edinburgh University Press.

Granholm, K. (2014) Dark Enlightenment: The Historical, Sociological, and Discursive Contexts of Contemporary Esoteric Magic. Leiden; Boston: Brill. 
Green, D. (2012) "What Men Want? Initial Thoughts on the Male Goddess Movement," Religion and Gender, 2(2), pp. 305-327.

Hakl, H.T. (2018) "Deification as a Core Theme in Julius Evola's Esoteric Works," Correspondences, 6(2), pp. 145-171.

Hanegraaff, W.J. (2002) "From the Devil's Gateway to the Goddess Within: The Image of the Witch in Neopaganism," in Kloppenborg, R. and W.J. Hanegraaff (eds.) Female Stereotypes in Religious Traditions. Leiden: Brill, pp. 295-312.

Hanegraaff, W.J. (2012) Esotericism and the Academy. Rejected Knowledge in Western Culture. Cambridge: Cambridge University Press.

Hedenborg White, M. (2013) "To Him the Winged Secret Flame, to Her the Stooping Starlight," Pomegranate, 15(1-2), pp. 102-121.

Hedenborg White, M. (2020) The Eloquent Blood: The Goddess Babalon and the Construction of Femininities in Western Esotericism. New York: Oxford University Press.

Jeffreys, S. (1987) "Butch and Femme: Now and Then," Gossip, 5, pp. 65-95.

Johnston, J. (2014) “A Deliciously Troubling Duo: Gender and Esotericism," in Asprem, E. and Granholm, K. (eds.) Contemporary Esotericism. Abingdon, Oxon.: Routledge, pp. 410-425.

Johnston, J. (2015) "Gender and the Occult," in Partridge, C. (ed.) The Occult World. Abingdon, Oxon.: Routledge, pp. 681-691.

Kaczynski, R. (2010) Perdurabo: The Life of Aleister Crowley. 2nd ed. Berkeley, CA: North Atlantic Books.

Kraft, S-E. (1999) The Sex Problem: Political Aspects of Gender Discourse in the Theosophical Society 1875-1930. PhD Diss., University of Bergen.

Lapovsky Kennedy, E., and M.D. Davis. (1993) Boots of Leather, Slippers of Gold: The History of a Lesbian Community. New York; London: Routledge.

Linden, R.R., Pagano, D.R., Russell, D.E.H., and Star, S.L. (1982) Against Sadomasochism: A Radical Feminist Analysis. East Palo Alto: Frog in the Well.

Lowry, E.S. (2017) Invisible Hosts: Performing the Nineteenth-Century Spirit Medium's Autobiography. Albany: suny Press.

MacKinnon, C.A. (1982) "Feminism, Marxism, Method, and the State: An Agenda for Theory," Signs, $7(3)$, pp. 515-544.

Mayer, G. (2009) "Magicians of the Twenty-First Century: An Attempt at Dimensioning the Magician's Personality," Magic, Ritual, and Witchcraft, 4(2), pp. 176-206.

McCann, H. (2018) Queering Femininity: Sexuality, Feminism, and the Politics of Presentation. London: Routledge.

Mueller, M. (2017) "If All Acts of Love and Pleasure Are Her Rituals, What about BDSM? Feminist Culture Wars in Contemporary Paganism," Theology and Sexuality," 24(2), pp.1-14.

Owen, A. (1989) The Darkened Room: Women, Power and Spiritualism in Late Victorian England. London: Virago. 
Owen, A. (2004) A Place of Enchantment: British Occultism and the Cult of the Modern. Chicago: University of Chicago Press.

Qadisha, A. (1996) "Procession of Babalon: The Evolution of the Goddess through the Aeons," Sexmagick.com. Accessed January 15, 2017 [https://web-beta.archive.org].

Rubin, G. (1984) "Thinking Sex: Notes for a Radical Theory of the Politics of Sexuality," in Vance, C.S. (ed.) Pleasure and Danger: Exploring Female Sexuality, pp. 267-321. Boston: Routledge and Kegan.

Schippers, M. (2007) "Recovering the Feminine Other: Masculinity, Femininity, and Gender Hegemony," Theory and Society, 36(1), pp. 85-102.

Scott, Joan W. (1986) "Gender: A Useful Category of Historical Analysis," The American Historical Review, 91(5), pp. 1053-1075.

Skeggs, B. (2001) “The Toilet Paper: Femininity, Class and Mis-Recognition," Women's Studies International Forum, 24(3/4), pp. 295-307.

Snoek, J.A.M. and Heidle, A. (2008) Women's Agency and Rituals in Mixed and Female Masonic Orders. Leiden: Brill.

Soror Syrinx (2014) Traversing the Scarlet Path. N.p.: America Star Books.

Strube, J. (2016) “The 'Baphomet' of Eliphas Lévi: Its Meaning and Historical Context," Correspondences, 4, pp. 37-79.

Styers, R. (2004) Making Magic: Religion, Magic, and Science in the Modern World. New York: Oxford University Press.

Vance, C.S. (ed.) (1992) Pleasure and Danger: Exploring Female Sexuality. London: Pandora Press.

Walker, L. (2012) "The Future of Femme: Notes on Femininity, Aging and Gender Theory," Sexualities, 15(7), pp. 795-814.

Warner, M. (ed.) (1993) Fear of a Queer Planet. Queer Politics and Social Theory. Minneapolis: University of Minnesota Press.

West, C. and Zimmerman, D. (1987) "Doing Gender," Gender and Society, 1(2), pp. $125^{-151 .}$

Williams, B. (2009) "Feminist Thelema," in Beauty and Strength: Proceedings of the Sixth Biennial National Ordo Templi Orientis Conference. Riverside, CA: Ordo Templi Orientis. 